Research Article

\title{
Impact of Organic Matter, Inorganic, and Biofertilizer Combination on Soybean Yield in Entisol Soil of Indonesia
}

\author{
Didik Sucahyono $\mathbb{D D}^{1}$ Yudi Widodo ${ }^{\mathrm{D}}{ }^{1}$ ' Runik D. Purwaningrahayu ${ }^{1}{ }^{1}$ \\ Henny Kuntyastuti $\mathbb{D}^{1},{ }^{1}$ Herdina Pratiwi $\mathbb{D}{ }^{1}{ }^{1}$ Sri Wahyuningsih $\mathbb{D}^{1},{ }^{1}$ Titik Sundari $\mathbb{D}$, ${ }^{1}$ \\ Rudy Soehendi $\mathbb{D}^{1},{ }^{1}$ I. Gusti K. D. Arsana $\mathbb{D}^{2},{ }^{2}$ and Made J. Mejaya $\mathbb{D}^{1}$ \\ ${ }^{1}$ Indonesian Legume and Tuber Crops Research Institute (ILETRI), Jl. Raya Kendalpayak Km 8, P.O. Box 66, Malang 65101, \\ East Java, Indonesia \\ ${ }^{2}$ Bali Agricultural Technology Assessment Institute, Jl. By Pass Ngurah Rai No. 1A, Denpasar 80222, Indonesia
}

Correspondence should be addressed to Made J. Mejaya; mmejaya@yahoo.com

Received 3 September 2021; Accepted 10 November 2021; Published 30 November 2021

Academic Editor: Vera Popovic

Copyright (c) 2021 Didik Sucahyono et al. This is an open access article distributed under the Creative Commons Attribution License, which permits unrestricted use, distribution, and reproduction in any medium, provided the original work is properly cited.

\begin{abstract}
The study aimed to investigate an effect of organic fertilizer applied to rice in the first planting season for unfertilized soybean as second crop followed by inorganic and biofertilizer applied in the third season on soybean growth and yield under the ricesoybean-soybean cropping pattern in 2016/2017. The main plot was organic: (1) without organic amendment, (2) $10 \mathrm{t} \cdot \mathrm{ha} \mathrm{a}^{-1} \mathrm{of}^{-}$ chicken manure, and (3) $10 \mathrm{t} \cdot \mathrm{ha}^{-1}$ precomposted rice straw. The subplot was inorganic $\mathrm{N}$ and $\mathrm{P}$ fertilizers and commercial biofertilizer (consisting of Rhizobium, nitrogen-fixing bacteria, and P-solubilizing bacteria) applied at planting of soybeans in the second dry season: (1) control (no inorganic and biofertilizer), (2) $50 \mathrm{~kg}$ urea ha ${ }^{-1}$, (3) $100 \mathrm{~kg} \mathrm{SP} 36 \cdot \mathrm{ha}^{-1}$, (4) $50 \mathrm{~kg}$ urea $+100 \mathrm{~kg}$ SP36 ha ${ }^{-1}$, (5) biofertilizer, (6) biofertilizer $+25 \mathrm{~kg}$ urea ha ${ }^{-1}$, (7) biofertilizer $+75 \mathrm{~kg} \mathrm{SP36} \mathrm{ha}{ }^{1}$, and (8) biofertilizer $+25 \mathrm{~kg}$ urea $+75 \mathrm{~kg} \mathrm{SP} 36 \mathrm{ha}^{-1}$. Soybean planted on the first dry season after rice harvested was not fertilized (untreated). The results showed that the chicken manure amendment increased grain yield of soybean in the second season, i.e., from $1.03 \mathrm{t}$.ha ${ }^{-1}$ (without organic amendment) to $1.27 \mathrm{t} \cdot \mathrm{ha}^{-1}$, an increase of $23 \%$. There was no effect of rice straw on soybean grain yield. In the third season, however, the residual effect of straw compost or chicken manure increased soybean grain yield by $8 \%$ and $20 \%$, respectively. Both straw compost and chicken manure also showed a positive effect on the use of inorganic and biofertilizers in increasing soybean productivity.
\end{abstract}

\section{Introduction}

Increasing the productivity of soybean (Glycine max (L.) Merr.) can be done by the integrated land and nutrient management. The efficiency and effectiveness of nutrient management refers to the sustainability of land carrying capacity which becomes a necessity [1]. Soybean plants are mostly grown in paddy fields following the cropping pattern of rice-rice-soybean, or rice-soybean-soybean. In monoculture, the plough tillage and no-tillage generated a higher income per ha than the soybean grown in crop rotation. During this period, the increase of soybean production is more on the use of inorganic fertilizers, due to it is easy process, practical nature, and availability, as well as highyielding varieties that are responsive to fertilizer application.

The use of chemical fertilizers and less attention to the use of organic materials lead to reduced fertility of a lot of paddy soil. One indicator of the soil fertility decline is from C-organic levels [2]. The results of the soil analysis of 30 locations of Indonesian paddy fields taken randomly reported that $68 \%$ of them have C-organic content of less than $1.5 \%$ and only $9 \%$ had levels of more than $2 \%$ [3]. Crop residue management becomes very important in the aspect of long-term soil fertility in a cropping pattern.

Organic materials should be a top priority in the management for maintaining sustainable agricultural 
systems. Incorporation of crop residues can alter microbial processes in the soil, thereby affecting the availability of nutrients and, in turn, the production of crops [4]. In alfisol soil with low organic-C levels, the addition of chicken manure at amount of $10 \mathrm{t} \cdot \mathrm{ha}^{-1}$ increased soybean grain yield by $0.25 \mathrm{thh} \mathrm{h}^{-1}$ [5]. The organic input commonly used in paddy field is rice straw. The tendency of farmers in Indonesia is burning rice straw after harvest. This trend is not favorable because it eliminates most of the potential benefits of rice straw. Application of $5 \mathrm{t} \cdot \mathrm{ha}^{-1}$ rice straw has been reported to supply $30 \mathrm{~kg} \mathrm{~N}, 5 \mathrm{~kg} \mathrm{P}, 2.5 \mathrm{~kg} \mathrm{~S}, 75 \mathrm{~kg} \mathrm{~K}$, and $100 \mathrm{~kg}$ of $\mathrm{Si}$, in addition to 2 tonnes of carbon which is the source of energy for the activities of microorganisms in soil [3].

The quality and productivity of soil and crop cultivation in sustainable agriculture can be maintained by using organic and inorganic fertilizer inputs. The effect of organic fertilizer application maintains and improves physical, chemical, and biological soil fertility and plant productivity [6]. Application of organic matter in paddy soil by using straw or manure has long been carried out by farmers. However, significant amounts of at least $10 \mathrm{t} \cdot \mathrm{ha}^{-1}$ were required to get the most out of the use of the organic materials as fertilizers (incorporated to the soil) [7]. Therefore, the appropriate technology for organic material use in agricultural land is required, so these large doses can be used as efficient as possible. In relation with this, the study will assess the effect of the use of organic materials for increasing crop productivity and its residual effect on the effectiveness of inorganic and bio fertilizers, by (1) utilizing the residual effect of organic matter from the previous to the next planting season and (2) combining the residual effect of organic matter with other inputs in the form of inorganic and biological fertilizers.

The objective of this study was to examine the effect of organic, inorganic, and biofertilizers on plant growth and grain yield of soybean.

\section{Materials and Methods}

2.1. Study Area. The research was conducted in a paddy field of entisol soil type in the first and second dry season following the cropping pattern rice-soybean-soybean in 2016/ 2017. The research site was located in the Genteng district, Banyuwangi regency, East Java Province, Indonesia, at the coordinates of $-8^{\circ} 22^{\prime} 0.01^{\prime \prime}$ South Latitude and $114^{\circ} 09^{\prime} 0.00^{\prime \prime}$ East Longitude.

2.2. Description of Experimental Design. Treatment was arranged in a split plot design with three replications. The main plots were organic fertilizer (applied at the time of land preparation for rice in the rainy season): (1) no organic fertilizer, (2) $10 \mathrm{t} \cdot \mathrm{ha}^{-1}$ chicken manure, (3) $10 \mathrm{t} \cdot \mathrm{ha}^{-1}$ straw compost. The subplots were inorganic $\mathrm{N}$ and $\mathrm{P}$ fertilizer as well as commercial biofertilizer (consisted of $\mathrm{N}$-fixing Rhizobium and P-solubilizing bacteria) that were applied at planting of soybeans in the second dry season: (1) control (without inorganic or biofertilizer), (2) $50 \mathrm{~kg}_{\mathrm{urea} \mathrm{ha}}{ }^{-1}$, (3)

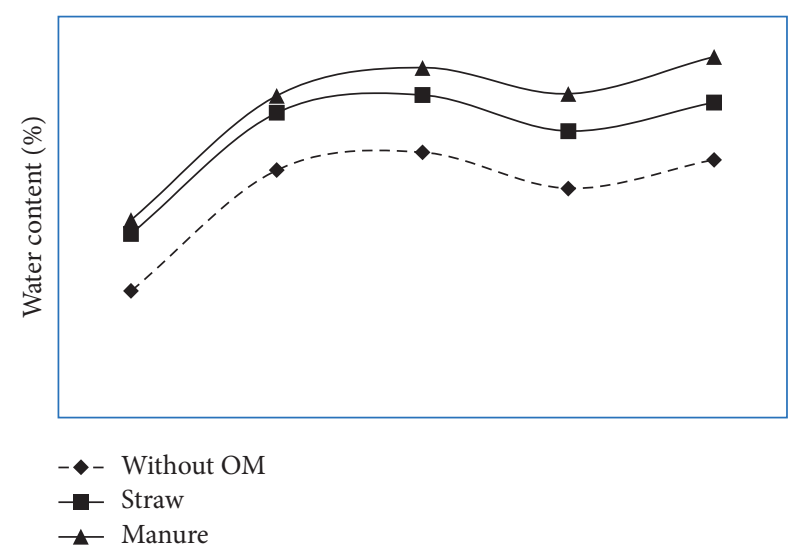

FIgURE 1: Effect of organic matter (OM) applied in the previous season (rice) on soil water content of the next planting season (soybean I) under the rice-soybean-soybean cropping pattern.

$100 \mathrm{~kg} \mathrm{SP} 36 \mathrm{ha}^{-1}$, 4) $50 \mathrm{~kg}$ urea ha ${ }^{-1}+100 \mathrm{~kg} \mathrm{SP} 36 \mathrm{ha}^{-1}$, (5) biofertilizer, (6) biofertilizer $+25 \mathrm{~kg}$ urea ha ${ }^{-1}$, (7) biofertilizer $+75 \mathrm{~kg} \mathrm{SP} 36 \mathrm{ha}^{-1}$, and (8) biofertilizer $+25 \mathrm{~kg}$ urea $\mathrm{ha}^{-1}+75 \mathrm{~kg} \mathrm{SP} 36 \mathrm{ha}^{-1}$. Soybean planted on the first dry season after rice harvest was not fertilized (untreated).

Treatment plot size was $4 \mathrm{~m} \times 5 \mathrm{~m}$, with a plant spacing of $40 \mathrm{~cm} \times 15 \mathrm{~cm}$, two plants per hill. The soybean variety planted was Anjasmoro. To inoculate the seed by biological fertilizers, the seeds were first covered by Arabic Gum solution and then biofertilizer was applied according to experimental treatments. All the seeds were sown soon after inoculation. Before planting, the soil and organic fertilizer were analyzed to obtain the data of $\mathrm{pH}$, organic- $\mathrm{C}, \mathrm{N}, \mathrm{P}$, and K.

2.3. Data Analysis. Data were collected from soybean crops in the first and second dry season. At the vegetative phase (45 dap), a sample of 5 plants plot $^{-1}$ was measured for plant dry weight and $\mathrm{P}$ content in the plant. At harvest, samples of 10 plants plot $^{-1}$ were measured for plant height and number of pods plant ${ }^{-1}$, while the harvested plots of $4 \mathrm{~m} \times 3 \mathrm{~m}$ were observed for grain yield. Data collected were subjected to statistical analysis by using Duncan's Multiple Range Test (DMRT) at $5 \%$ probability level applied to compare the differences among treatment means.

\section{Results}

3.1. Residual Effect of Organic Amendment on Soybean in the First Dry Season. Long-term effects of organic amendment were determined by the type of organic material used. At the first dry season or one season after amendment, the residual effects of straw compost tended to increase the soybean plant height and dry matter although not significantly different from those of control (without organic amendment), while the residual effect of chicken manure significantly increased plant dry matter, nodule dry weight, and plant height of soybean (Figure 1).

The improvement of plant growth and nodulation on the chicken manure amended soil was followed by an increase in 
TABLE 1: Effect of organic fertilizer applied in the rainy season on nodule dry weight, plant dry matter, and plant height of soybean in the first dry season.

\begin{tabular}{|c|c|c|c|}
\hline Organic fertilizer & Nodule dry weight (mg plant ${ }^{-1}$ ) & Plant dry matter weight (g plant ${ }^{-1}$ ) & Plant height $(\mathrm{cm})$ \\
\hline Without fertilizer & $210 \mathrm{~b}$ & $33.7 \mathrm{~b}$ & $53.6 \mathrm{~b}$ \\
\hline Straw compost & $220 \mathrm{~b}$ & $37.7 \mathrm{ab}$ & $56.5 \mathrm{ab}$ \\
\hline Chicken manure & $260 \mathrm{a}$ & $40.9 \mathrm{a}$ & $58.4 \mathrm{a}$ \\
\hline
\end{tabular}

Numbers in one column followed by the same letter are not significantly different at LSD 5\%.

TABLE 2: Effect of organic fertilizer applied in the rainy season on 100 seed weight, pod field number, and grain yield of soybean in the first dry season.

\begin{tabular}{lccc}
\hline Organic fertilizer & 100 seed weight $(\mathrm{g})$ & Pod field number plant $^{-1}$ & Grain yield $\left(\mathrm{t} \mathrm{ha}^{-1}\right)$ \\
\hline Without fertilizer & $8.43 \mathrm{~b}$ & $39 \mathrm{~b}$ & $1.03 \mathrm{~b}$ \\
Straw compost & $8.83 \mathrm{ab}$ & $45 \mathrm{ab}$ & $1.19 \mathrm{ab}$ \\
Chicken manure & $9.06 \mathrm{a}$ & $48 \mathrm{a}$ & $1.27 \mathrm{a}$ \\
\hline
\end{tabular}

Numbers in one column followed by the same letter are not significantly different at LSD 5\%.

TABLE 3: Effect of organic fertilizer applied in the rainy season on nodule dry weight, plant dry matter, and plant height of soybean in the second dry season.

\begin{tabular}{|c|c|c|c|}
\hline Organic fertilizer & Plant height $(\mathrm{cm})$ & Nodule dry weight (g plant ${ }^{-1}$ ) & Plant dry matter (g plant ${ }^{-1}$ ) \\
\hline Without fertilizer & $594 \mathrm{~b}$ & $0.19 \mathrm{~b}$ & $35.1 \mathrm{~b}$ \\
\hline Straw compost & $683 a$ & $0.20 \mathrm{~b}$ & $37.8 \mathrm{ab}$ \\
\hline Chicken manure & $697 \mathrm{a}$ & $0.30 \mathrm{a}$ & $39.6 \mathrm{a}$ \\
\hline
\end{tabular}

Numbers in one column followed by the same letter are not significantly different at LSD 5\%.

grain yield from $1.03 \mathrm{t} \cdot \mathrm{ha}^{-1}$ (without organic amendment) to $1.27 \mathrm{t} \cdot \mathrm{ha}^{-1}$, an increase of $23 \%\left(0.24 \mathrm{t} \cdot \mathrm{ha}^{-1}\right)$. The increase in grain yield was also supported by an increase in the number of pods per plant and 100 seed weight. Conversely, the residual effect of straw compost has not been seen in increasing grain yield of soybean. This might be at the first dry season, when the straw had not been completely decomposed naturally. This was probably due to its low nitrogen levels (Tables 1 and 2).

\subsection{Residual Effect of Organic Amendment on Soybean in the} Third Season. In the third season, a significant effect of organic fertilizer residues from the previous two seasons on the increase in plant height, nodule weight, and weight of soybean plants was seen, but the interaction with inorganic and biofertilizers was not significant for the three variables (Table 3). Treatment of chicken manure, like the previous season, still showed advantages in increasing nodule weight, plant weight, and plant height compared to that of the straw compost treatment and without organic fertilizer. In the third season after amendment, straw compost, the same as in the previous season, was less effect on plant growth parameters, but it showed a significant effect on the increase in dry weight of root nodules, while chicken manure, as in the previous season, still showed superiority in increasing nodule weight, plant dry matter, and plant height compared to straw compost or without organic amendment (Table 3).

3.3. The Role of Organic Fertilizers in Increasing the Productivity of Soybean Plants. In contrast to the growth parameters, soybean productivity was influenced by the interaction
TABLE 4: Effect of organic fertilizer from the rainy season and inorganic and biofertilizers applied in the second dry season on the grain yield of soybean.

\begin{tabular}{|c|c|c|c|}
\hline \multirow[b]{2}{*}{ Fertilizer } & \multicolumn{3}{|c|}{ Grain yield $\left(\mathrm{t} \mathrm{ha}^{-1}\right)$} \\
\hline & $\begin{array}{l}\text { Without } \\
\text { organic } \\
\text { fertilizer }\end{array}$ & $\begin{array}{c}\text { Straw } \\
\text { compost }\end{array}$ & $\begin{array}{l}\text { Chicken } \\
\text { manure }\end{array}$ \\
\hline Without fertilizer (control) & $1.87 \quad 1$ & 2.02 hijk & $2.19 \mathrm{def}$ \\
\hline $50 \mathrm{~kg}$ urea $/ \mathrm{ha}$ & 1.99 ijk & $2.13 \mathrm{efg}$ & $2.33 \mathrm{ab}$ \\
\hline $100 \mathrm{~kg} \mathrm{SP36/ha}$ & $1.88 \quad 1$ & $2.08 \mathrm{ghi}$ & $2.27 \mathrm{bcd}$ \\
\hline $50 \mathrm{~kg}$ urea $+100 \mathrm{~kg}$ SP36 $/ \mathrm{ha}$ & $1.93 \mathrm{kl}$ & 2.14 efg & $2.25 \mathrm{bcd}$ \\
\hline Biofertilizer & 2.05 ghij & 2.22 & $2.34 \mathrm{ab}$ \\
\hline Biofertilizer $+25 \mathrm{~kg}$ urea $/ \mathrm{ha}$ & $2.11 \mathrm{fgh}$ & $2.25 \mathrm{bcd}$ & $2.39 \quad \mathrm{a}$ \\
\hline Biofertilizer $+75 \mathrm{~kg}$ SP36 $/ \mathrm{ha}$ & $1.95 \mathrm{jkl}$ & 2.21 cdef & $2.31 \mathrm{abc}$ \\
\hline $\begin{array}{l}\text { Biofertilizer }+25 \mathrm{~kg} \\
\text { urea }+75 \mathrm{~kg} \text { SP } 36 / \mathrm{ha}\end{array}$ & 2.07 ghi & $2.27 \mathrm{bcd}$ & 2.41 \\
\hline
\end{tabular}

Numbers in one column and row followed by the same letter are not significantly different at DMRT $5 \%$.

between organic amendment and the treatment of inorganic and biofertilizers. Chicken manure and straw compost amendment significantly influence the effectiveness of urea and biofertilizer in increasing the number of pods and grain yield of soybean (Tables 4 and 5).

The application of $50 \mathrm{~kg}$ urea $\mathrm{ha}^{-1}$ or biofertilizer resulted in the highest grain yield compared to the other treatments. On unamended soil, application of $50 \mathrm{~kg}$ urea $\mathrm{ha}^{-1}$ or biofertilizer resulted in a grain yield of $1.99 \mathrm{t} \cdot \mathrm{ha}^{-1}$ and $2.05 \mathrm{t} \cdot \mathrm{ha}^{-1}$, respectively, an increase of $6.5 \%$ and $9.6 \%$ over control $\left(1.87 \mathrm{t} \cdot \mathrm{ha}^{-1}\right)$. On soil amended with straw compost, the increase in grain yield in both the treatment was to be $14 \%$ and $19 \%$, and the highest increase was 
TABLE 5: Effect of organic fertilizer from the rainy season and inorganic and biofertilizer applied in the second dry season on pod field number plant ${ }^{-1}$ of soybean.

\begin{tabular}{|c|c|c|c|}
\hline \multirow[b]{2}{*}{ Fertilizer } & \multicolumn{3}{|c|}{ Pod field number plant ${ }^{-1}$} \\
\hline & $\begin{array}{l}\text { Without } \\
\text { organic } \\
\text { fertilizer }\end{array}$ & $\begin{array}{l}\text { Straw } \\
\text { compost }\end{array}$ & $\begin{array}{l}\text { Chicken } \\
\text { manure }\end{array}$ \\
\hline Without fertilizer (control) & 33.2 hi & $38.4 \mathrm{gh}$ & 51.0 ef \\
\hline $50 \mathrm{~kg}$ urea/ha & 37.7 ghi & $42.6 \mathrm{~g}$ & $62.7 \mathrm{abc}$ \\
\hline $100 \mathrm{~kg} \mathrm{SP36/ha}$ & $30.8 \quad \mathrm{i}$ & $40.4 \mathrm{gh}$ & $57.2 \mathrm{cde}$ \\
\hline $50 \mathrm{~kg}$ urea $+100 \mathrm{~kg}$ SP36/ha & 37.7 ghi & 37.8 ghi & $54.0 \mathrm{de}$ \\
\hline Biofertilizer & $42.5 \mathrm{~g}$ & $44.0 \mathrm{fg}$ & $59.0 \mathrm{bcd}$ \\
\hline Biofertilizer $+25 \mathrm{~kg}$ urea/ha & $40.7 \mathrm{gh}$ & $63.5 \mathrm{abc}$ & $67.4 \quad \mathrm{a}$ \\
\hline Biofertilizer + $75 \mathrm{~kg} \mathrm{SP36/ha}$ & 37.4 ghi & $41.3 \mathrm{~g}$ & 38.7 cde \\
\hline $\begin{array}{l}\text { Biofertilizer }+25 \mathrm{~kg} \text { urea }+75 \mathrm{~kg} \\
\text { SP36/ha }\end{array}$ & $38.6 \mathrm{gh}$ & 51.0 & $44.3 \mathrm{ab}$ \\
\hline
\end{tabular}

Numbers in one column and row followed by the same letter are not significantly different at DMRT 5\%.

obtained on the soil amended with chicken manure that was $24 \%$ and $25 \%$. In soil amended with chicken manure, the treatment of biofertilizer $+25 \mathrm{~kg}$ urea ha ${ }^{-1}$ showed the highest grain yield but not significantly different compared to that of $50 \mathrm{~kg}$ urea ha ${ }^{-1}$ or biofertilizer treatment. This suggests that the use of biofertilizer was able to replace the use of chemical fertilizers as it gives results equivalent to those obtained at $50 \mathrm{~kg}$ urea ha ${ }^{-1}$ fertilizer. In contrast to fertilizer N, P fertilizer application of $100 \mathrm{~kg} \mathrm{SP} 36 \mathrm{ha}^{-1}$ had no effect on the growth and productivity of soybean plants. This suggests that, in the research sites, which are technically irrigated paddy field, $\mathrm{P}$ is not a limiting nutrient for soybean crop in the second season after rice, due to high $\mathrm{P}$ accumulation in paddy soil. On the other hand, the use of biological fertilizers containing P-solubilizing bacteria is more useful for mining $\mathrm{P}$ accumulated in the soil. The soybean plant in this season, on the other hand, is more responsive to $\mathrm{N}$ (urea) fertilizer. Nitrogen is a nutrient that is easily lost, partly with irrigation water when drying after rice. Loss of $\mathrm{N}$ can also occur due to transportation of soybean plants from the previous season that were neither $\mathrm{N}$ nor $\mathrm{P}$ fertilized, with assumptions there are still enough nutrients from fertilization for rice.

Soybean productivity is influenced by the interaction between organic fertilizer treatment with inorganic and biological fertilizers. The residual chicken manure and straw compost had a significant effect on increasing the effectiveness of $\mathrm{N}$ fertilizer and biofertilizers on the variables of the number of field pods and soybean seed yield (Table 4). Without organic fertilizer, application of $50 \mathrm{~kg} \mathrm{urea} \mathrm{ha}^{-1}$ and Rhizoplus increased seed yields from $1.87 \mathrm{t} \cdot \mathrm{ha}^{-1}$ to $1.99 \mathrm{t} \cdot \mathrm{ha}^{-1}$ and $2.05 \mathrm{t} \cdot \mathrm{ha}^{-1}$, respectively. However, with straw compost, giving $50 \mathrm{~kg}$ of urea ha ${ }^{-1}$ and Rhizoplus, can increase the yield of seeds to $2.13 \mathrm{t} \cdot \mathrm{ha}^{-1}$ and $2.22 \mathrm{t} \cdot \mathrm{ha}^{-1}$. Meanwhile, the yield of seeds in the straw compost treatment was $2.02 \mathrm{t} \cdot \mathrm{ha}^{-1}$. In the treatment of chicken manure, the yield of seeds obtained was higher than that of straw compost, namely, $2.25 \mathrm{t} \cdot \mathrm{ha}^{-1}$, and the addition of other inputs in the form of urea or bio fertilizers did not increase the yield of seeds, except for the combination of biofertilizer $+25 \mathrm{~kg}$ urea $\mathrm{ha}^{-1}$ which gave the highest seed yield of $2.39 \mathrm{t}^{-\mathrm{ha}^{-1}}$. In soil containing organic fertilizer residues, the use of Rhizoplus, which, in addition to containing P-solubilizing bacteria, also contains $\mathrm{N}$-fixing bacteria, was able to reduce the need for $\mathrm{N}$ fertilizer of urea to plants. This yield can still be improved with the combination of Rhizoplus $+25 \mathrm{~kg}$ urea ha ${ }^{-1}$, which gives the highest yield of seeds under both the straw compost and chicken manure treatment as well.

\section{Discussion}

4.1. Residual Effect of Organic Amendment on Soybean in the First Dry Season. The effect of organic matter, especially chicken manure, in improving soybean growth and nodulation can be due to its ability to improve the texture and the air circulation of the soil so that the plant roots become deeper and wider $[8,9]$. Organic matter also made better soil environment for plant growth and microbial life, in particular rhizobium bacteria that form nodules on the roots of legumes [10].

4.2. Residual Effect of Organic Amendment on Soybean in the Third Season. Chicken manure that has a low content of organic-C and higher levels of $\mathrm{N}$ (Table 6) decays more quickly, so the effect was more apparent than straw compost which supposedly has not decomposed perfectly. Straw, in addition to the low nitrogen content and high organic-C (Table 6), has high lignin content [11]. Lignin is one of the organic materials that are difficult to decompose.

4.3. The Role of Organic Fertilizers in Increasing the Productivity of Soybean Plants. Biofertilizers, whose main components are $\mathrm{P}$-solubilizing and $\mathrm{N}$-fixing microbes, like other microbes in general, require optimal environmental conditions for growth and activity. The important growing environmental factors include $\mathrm{pH}$ and humidity. The optimal $\mathrm{pH}$ range for microbes is generally neutral or about neutral. The application of organic matter was able to change/improve soil $\mathrm{pH}$. In this study, soil $\mathrm{pH}$ was not observed, but from the results of previous studies (pot experiments) on several acidic and alkaline soils, it was seen that one season after immersion of organic matter in the soil, the $\mathrm{pH}$ generally changes towards/around neutral. The same result was reported by Soepardi [12] that, in tidal rice fields, immersion of organic matter had a major effect on changes in soil $\mathrm{pH}$, by increasing the $\mathrm{pH}$ from 5.0 to 6.5 after 90 days of incubation. Microbial cells can die due to drought; therefore, moisture or the availability of enough water is also needed for microbial life in the soil. Application of organic matter increases the soil's ability to retain water. This can be seen from the increase in soil water content in the organic fertilizer treatment compared to the organic fertilizer without (Figure 1). The positive effect of organic fertilizers on improving the physical and chemical properties of soil, including $\mathrm{pH}$ and soil moisture content, is that it was able to increase the effectiveness of inorganic and biological 
TABLE 6: Chemical properties of soil and organic matter.

\begin{tabular}{lcccccc}
\hline Soil organic matter & $\mathrm{pH} \mathrm{H}_{2} \mathrm{O}$ & C-organic (\%) & $\mathrm{P}(\%)$ & $\mathrm{N}(\%)$ & $\mathrm{C} / \mathrm{N} \mathrm{ratio}$ & $\mathrm{K}(\mathrm{me} / 100 \mathrm{~g})$ \\
\hline Without fertilizer & 6.5 & 1.4 & 0.0036 & 0.21 & 6.66 & 0.96 \\
Straw compost & - & 25.9 & 0.3100 & 0.61 & 42.45 & 0.60 \\
Chicken manure & - & 9.0 & 0.8000 & 1.66 & 5.42 & 0.88 \\
\hline
\end{tabular}
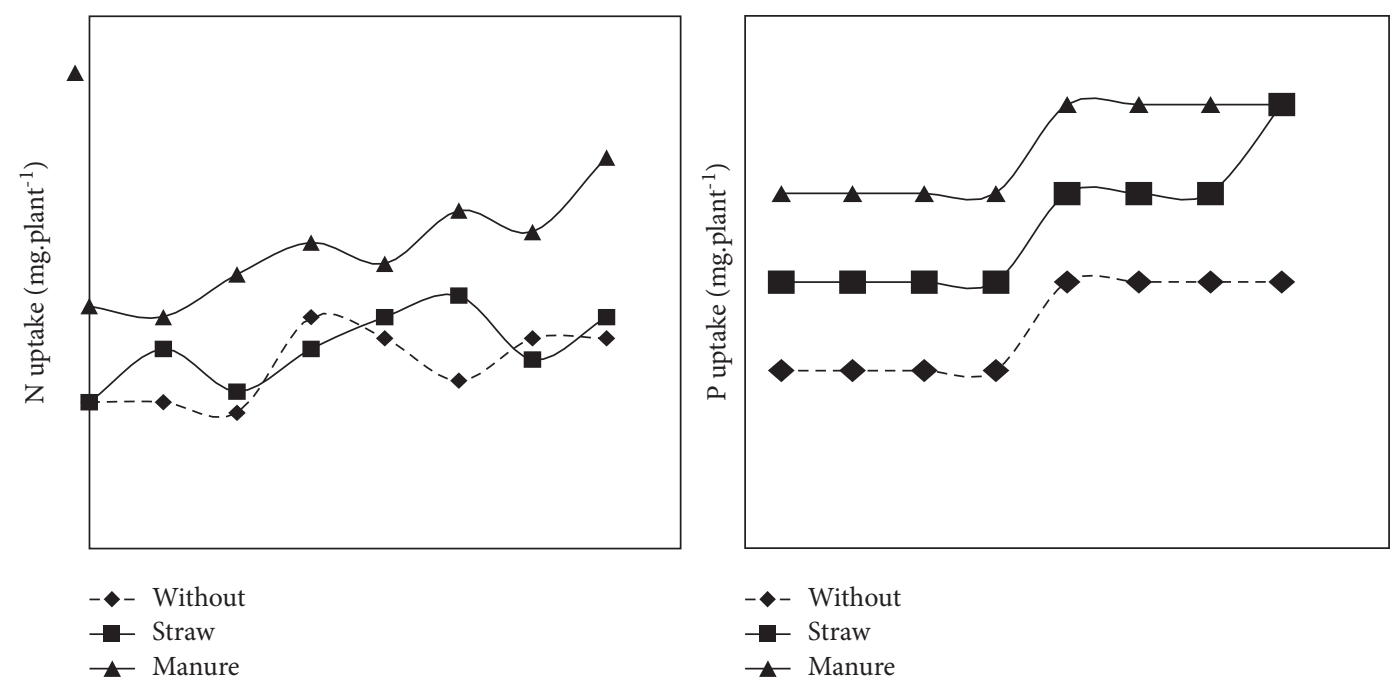

Figure 2: Effect of urea: $25 \mathrm{~kg} \cdot \mathrm{ha}^{-1}(25 \mathrm{~N})$ and $50 \mathrm{~kg} \cdot \mathrm{ha}^{-1}(50 \mathrm{~N})$, SP36: $75 \mathrm{~kg} \cdot \mathrm{ha}^{-1}$ (75 P) and $100 \mathrm{~kg} \cdot \mathrm{ha}^{-1}$ (100 P), and biofertilizer (Bio) on N and $\mathrm{P}$ uptake of the second soybean season under the rice-soybean-soybean cropping pattern.

fertilizers on soybean plants. This can be seen from the nutrient uptake in the treatment of urea, SP36, and biofertilizers which increased in soil treated with organic fertilizers compared to those without (Figure 2).

The evaluation of Bradyrhizobium did not give a clear effect on soybean yield and composition. Soybean seed yield and composition (protein, oil, and AAs concentration) were not affected by any of the inoculation strategies. There was a lack of response to inoculation on nodule number and relative abundance of ureides (RAU). Soils with previous soybean in the rotation or viable rhizobia populations create conditions in which seed or additional in-season soil inoculations, at V4 or R1 growth and development stages, did not produce any benefit on seed yield and composition [13]. Continuous cultivation, without application of organic inputs, significantly depleted total C content in the soil by $39-43 \%$ compared with treatments involving the addition of organic amendments. Microbial biomass carbon (Cmic) and mineralizable $\mathrm{C}$ increase following the addition of the organic inputs. The organic amendment significantly increases grain yield [14].

Soil organic matter and enzymes are essential for nutrient cycling and soil quality. Long-term use of manure is the best alternative to improve soil quality and microbial activity. The use of manure for 15 years increased organic matter, total $\mathrm{N}$, enzyme activity, including invertase, $\beta$-glucosidase, urease, acid phosphatase, alkaline phosphatase, and dehydrogenase activity in the soil [15]. Therefore, the application of organic fertilizers may increase soil organic- $\mathrm{C}$ content and reduce the use of inorganic fertilizers. Inorganic fertilizer application such as manure and soil conservation methods is an important recommendation in areas where there is frequent drought and erratic rainfall occurring to conserve the fertile agricultural environment. The sustainable land management practices reduce the likelihood of discontinued use of green revolution input technologies [16].

The application of organic (cow or poultry) manures combined with the recommended dose of inorganic fertilizers $(\mathrm{N}, \mathrm{P}, \mathrm{K}$, and $\mathrm{Ca}$ ) improved soil fertility status and increased the grain yield as well as grain quality of soybean [17]. The use of a late-maturing variety of soybean with lower rates of organic manure resulted in a finger millet yield comparable to farmers' practice, indicating that this option can be adopted by smallholder farmers who cannot produce sufficient organic manure. Planting of finger millet after a soybean precursor crop even without fertilizer application could give better yield and economic benefits as it saves $70-85 \%$ of chemical fertilizer costs compared to the farmers' practice [18].

The combination of conservation systems (no-tillage and minimum tillage) and crop rotation gave a higher soybean yield [19]. $\mathrm{N}$ and $\mathrm{P}$ uptake by seed and straw increased significantly from 0 to 75 and 75 to $100 \%$ recommended N, and a similar trend was found in $\mathrm{K}$ uptake by seed and straw. Agronomic efficiency, apparent recovery, and energy output were increased up to $100 \%$ recommended N. However, partial factor productivity was decreased significantly with the increase in $\mathrm{N}$ levels, and physiological efficiency was not influenced significantly by different $\mathrm{N}$ levels [20]. The right timing of rice straw incorporation into the soil and combined use of rice straw and mineral fertilizer could improve 
the short-term effectiveness to the plants. Continuous application of rice straw resulted in the improvement of soil fertility, plant growth, and $\mathrm{N}$ uptake by paddy rice and upland crops [21].

\section{Conclusions}

The findings of this study highlighted that the use of organic chicken manure in irrigated entisol rice fields (rainy season) has a real role up to two seasons and after that, in increasing soybean productivity in the first and second dry season. On the other hand, the effect of straw compost is seen in the third season (second dry season). The residue of chicken manure and straw compost has a significant role in increasing the effectiveness of urea and biofertilizers on soybean in the second dry season.

\section{Data Availability}

Data are available on request through a data access committee of the Indonesian Legume and Tuber Crops Research Institute (ILETRI).

\section{Conflicts of Interest}

The authors declare no conflicts of interest.

\section{Authors' Contributions}

D.S., Y.W., T.S., and M.J.M. conceptualized the study; R.D.P., N.P., H.K, and M.J.M. formulated the methodology; D.S., R.D.P., T.S., S.W., R.S., and H.P. conducted investigation and analysis; D.S., Y.W., N.P., H.P., H.K., and M.J.M. wrote the original draft; D.S., N.P., H.K., I.G.K.D.A., and M.J.M. wrote, reviewed, and edited the manuscript; R.D.P., T.S., and H.K. supervised the manuscript; and T.S., Y.W., and H.K. acquired funding. All authors have read and agreed to the published version of the manuscript.

\section{Acknowledgments}

The authors wish to thank the director of ILETRI for funding of this study, the Senior Field Technician who helped with field activities in Genteng during 2016/2017, and Miss Suryantini for her contribution to this manuscript. This study was funded in part from the Research and Development program provided by the Ministry of Agriculture of the Republic of Indonesia, DIPA 2016/2017.

\section{References}

[1] M. S. Aulakh and C. A. Grant, Integrated Nutrient Management for Sustainable Crop Production, The Haworth Press, New York, NY, USA, 2008.

[2] G. Dorota, A. M. Nowak, and A. Woźniak, "Yield and economic effectivenes of soybean grown under different cropping systems," International Journal of Plant Production, vol. 14, pp. $475-485,2020$.

[3] J. Pramono, "Kajian penggunaan pupuk organik pada padi sawah," Journal of Agro Science, vol. 6, no. 1, pp. 11-14, 2004.
[4] O. C. Horwáth and W. R. Horwath, "Decomposition of rice straw and microbial carbon use efficiency under different soil temperatures and moistures," Soil Biology and Biochemistry, vol. 32, no. 11-12, pp. 1773-1785, 2000.

[5] H. Kuntyastuti and T. Adisarwanto, "Pemupukan kalium pada kedelai di tanah vertisol dan regosol," Penelitian Pertanian, vol. 15, no. 1, pp. 10-15, 1996.

[6] H. Kuntyastuti, S. Sutrisno, and S. Ayu Dwi Lestari, "Effect of application of organic and inorganic fertilizer on soybean yield in lowland vertisols," Journal of Degraded and Mining Lands Management, vol. 8, no. 1, pp. 2439-2450, 2020.

[7] Suryantini and A. A. Rahmiana, "Peningkatan efektivitas pupuk anorganik dan rhizoplus untuk produktivitas kedelai di tanah regosol dan vertisol melalui penggunaan pupuk organic," in Proceedings of the Disampaikan Pada Seminar Hasil Penelitian Tanaman Kacang-Kacangan dan UmbiUmbian.di Balitkabi, Malang, Indonesia, 2000.

[8] I. S. Jo, "Effect of organic fertilizer on soil physical properties and plant growth," in Proceedings of the Use of Organic Fertilizer in Crop Production, pp. 25-32, Suwon, South Korea, June 1990.

[9] S. Raihan, "Respon tanaman kedelai terhadap sisa pemberian arang sekam padi dan kapur," Bulletin Pertanian Kindai, vol. 3, no. 1, pp. 1-8, 1992.

[10] J. Homchan, "Environmental constraints to nitrogen fixation and rhizobial survival," in Proceedings of the Paper Presented in BNF Training Course, vol. 15, Bangkok, Thailand, 1989.

[11] S. K. Catterjee and B. Nandi, "Biodegradation of wheat stubbles by soil micro organism and role of product on soil fertility," Plant and Soil, vol. 59, pp. 381-390, 1981.

[12] G. Soepardi, Bahan Organik Tanah Mineral Dalam Sifat Dan Ciri Tanah, pp. 6-25, Department of Ilmu Tanah IPB, Bogor, Indonesia, 1980.

[13] W. D. Carciochi, L. H. M. Rosso, M. A. Secchi et al., "Soybean yield, biological $\mathrm{N}_{2}$ fxation and seed composition responses to additional inoculation in the United States," Nature Research, vol. 9, no. 1, Article ID 19908, 2019.

[14] S. Ghosh, B. Wilson, S. Ghoshal, N. Senapati, and B. Mandal, "Organic amendments influence soil quality and carbon sequestration in the Indo-Gangetic plains of India," Agriculture, Ecosystems \& Environment, vol. 156, pp. 134-141, 2012.

[15] Q. Liang, H. Chen, Y. Gong, H. Yang, M. Fan, and Y. Kuzyakov, "Effects of 15 years of manure and mineral fertilizers on enzyme activities in particle-size fractions in a North China plain soil," European Journal of Soil Biology, vol. 60, pp. 112-119, 2014.

[16] S. Hassen, "The effect of farmyard manure on the continued and discontinued use of inorganic fertilizer in Ethiopia: an ordered probit analysis," Land Use Policy, vol. 72, pp. 523532, 2018.

[17] S. Khaim, M. A. Chowdhury, and H. B. K. Saha, "Organic and inorganic fertilization on yield and quality of soybean," Journal of the Bangladesh Agricultural University, vol. 11, no. 1, pp. 23-28, 2013.

[18] A. Zerihun and D. Haile, "The effect of organic and inorganic fertilizers on yield of two contrasting soybean varieties and residual nutrient effects on a subsequent finger millet crop," Agronomy, vol. 7, no. 42, pp. 1-15, 2017.

[19] H. P. d. Santos, R. S. Fontaneli, J. Pires, E. A. Lampert, A. M. Vargas, and A. C. Verdi, "Grain yield and agronomic traits in soybean according to crop rotation systems," Bragantia, vol. 73, no. 3, pp. 263-273, 2014.

[20] H. K. Virk, G. Singh, and G. S. Manes, "Nutrient uptake, nitrogen use efficiencies, and energy indices in soybean under 
various tillage systems with crop residue and nitrogen levels after combine harvested wheat," Journal of Plant Nutrition, vol. 43, no. 3, pp. 407-417, 2019.

[21] S. Takahashi, S. Uenosono, and S. Ono, "Short- and long-term effects of rice straw application on nitrogen uptake by crops and nitrogen mineralization under flooded and upland conditions," Plant and Soil, vol. 251, no. 2, pp. 291-301, 2003. 